MALANGA, Eliana Branco. A bíblia hebraica como obra aberta. São Paulo: Humanitas, 2005. 336p.

\title{
A Bíblia Hebraica, uma obra aberta
}

\section{Glauber Pereira Quintão*}

O livro A Bíblia Hebraica como obra aberta foi originalmente concebido como uma tese de doutorado defendida por Eliana Branco Malanga, em 2002, no programa de Língua Hebraica, Literatura e Cultura Judaicas da faculdade de Letras da Universidade de São Paulo. O estudo de Malanga visa a, basicamente, verificar as possibilidades de se extender o conceito de "obra aberta", cunhado por Umberto Eco, para uma leitura da Bíblia Hebraica. Esse conceito, tomado da teoria semiológica, compreende a designação das obras de arte que admitem "múltiplas possibilidades de decodificação em virtude da densidade de significados" que possuem (p. 19). A abertura das interpretações do texto bíblico, no entanto, parecem extrapolar os limites estruturais e permite o reconhecimento dessa abertura em um sentido muito mais amplo.

A leitura da Bíblia como "obra aberta" contrasta mais radicalmente com as leituras de pretensão científica e objetiva desse mesmo texto. Enquanto estas buscariam a univocidade, um sentido exato que designa uma coisa determinada na realidade, o referente, portanto; a obra de arte exige uma leitura que respeite a multivocidade, sendo assim, o referente ou o que possa determinar o seu fechamento e a exclusividade de um único significado estaria fora de cogitação. Deve-se apontar, entretanto, o fato de que o Tanach (a Bíblia Hebraica) não é, propriamente, uma obra de arte e que, por isso, é necessário ter cuidado ao se lê-la valendo-se desse conceito, já que: "isso pode evitar armadilhas como as que tantas vezes enganaram os estudiosos da Bíblia, que viam imagens figuradas em descrições de fatos corriqueiros, como mais tarde se pôde descobrir por meio da arqueologia" (p. 77). Uma leitura mais acurada da Bíblia percebe, assim, nuanças imbricadas de textos mais ou menos abertos. Mesmo os textos, cujo referente se determina, não oferecem signos lingüísticos completamente fechados, isso porque: "A riqueza de um signo não se esgota na identificação de seu referente, pois, como afirma Eco, o significado de 'vaca' na vida de um hindu e de um ocidental são completamente diferentes. Para resumir, podemos dizer que o significado é construído socialmente" (p. 156). Dessa forma, nem os achados concretos da arqueologia não são capazes de esgotar o significado de qualquer objeto encontrado.

O Tanach se forma por uma coleção de coletâneas e possui textos poéticos e míticos (que, por sua densidade simbólica, se enquadrariam de forma adequada ao conceito de "obra aberta"), no entanto, há também os textos legais e históricos que possuem referente e deve-se, pois, respeitar sua univocidade. O estudo que se quer mais sutil e mais rico deve levar isso em conta. Assim como o fundamentalismo é indesejado, o seu extremo oposto, o relativismo, também se constitui como exagero e distorção da leitura da Bíblia. Uma leitura relativista da Bíblia seria a atribuição de sentido simbólico a todos os textos a despeito de sua intrínseca intenção de univocidade. Se uma das grandes inovações do judaísmo é a construção da percepção do tempo histórico, respeitar as designações literais é extremamente importante. O tempo histórico é justamente um tempo determinado e unívoco, que não se repete.

A abertura em sentido lato exigiria, portanto, no que se refere ao texto bíblico, uma abordagem ampla. A bíblia hebraica, além da pluralidade determinada por sua estrutura poética e pelo seu conteúdo mítico, apresenta inúmeras contradições e lacunas que deixam em aberto questões importantes como: a autoria; a datação; a precisão lingüística; a determinação da existência de autores que imitam um estilo mais antigo; a distinção entre mito e realidade; a distinção de textos unidos por justaposição. Por exemplo, nos recentes estudos sobre a Torá (composta pelos cinco primeiros livros bíblicos), determina-se a existência da compilação de quatro fontes distintas: a Javísta, a Eloísta, a Sacerdotal e a 
Deuteronomísta. Essas fontes possivelmente pertenceriam a diferentes autores e a diferentes épocas. Não há, porém, sequer uma unanimidade na distinção dessas fontes: "Costuma-se datar P [de Priestly, ou Sacerdotal, em português] como posterior ao exílio porque parece haver uma semelhança entre os conceitos expostos nessa fonte e o Livro das Crônicas" (p. 91). Pelo tom hipotético dessa referência, nota-se a dificuldade de se precisar a datação da chamada fonte Sacerdotal. Constata-se, também, essa mesma dificuldade para a maioria dos livros que compõem o Tanach: "Os livros históricos dos neviim, chamados de 'profetas anteriores' (...) são geralmente atribuídos ao autor deuteronomista". Isso mostra que mesmo os avanços científicos ainda não foram capazes, em virtude da distância da origem dos textos bíblicos, de determinar informações que, no entanto, são, a princípio, unívocas. Não somente pela antiguidade, como já se disse, mas por questões ainda mais corriqueiras como: "Para dar forma à Tora, os compiladores teriam selecionado 'tudo aquilo que se acredita ser a genuína palavra de Deus', sem modificar o material recolhido" (p. 126). A expressão "tudo aquilo que se acredita" lembra o fato de que homens comuns, sujeitos a erros, foram responsáveis pela compilação e pela seleção, ou escolha, dos textos. Além disso, é possível que os compiladores das quatro fontes tenham feito acréscimos aos textos.

Mesmo os textos considerados fechados, embora não segundo o conceito estrito de "obra aberta", mantêm relativa abertura, pois demandam interpretações, conjecturas, comentários, análises e discussões. Todo texto legível é, pois, sujeito a aberturas. A dificuldade determinada pela tradução, ou pela simples recuperação semântica, é outro fator que instauraria aberturas no texto. Como é sabido, embora recoberto de inúmeras interpretações rabínicas, o hebraico bíblico oferece sérios e instigantes problemas para os leitores contemporâneos. Em primeiro lugar, esses problemas advêm da própria antiguidade, que dificulta reconstituir os significados contextuais do texto. A força literária de que a Bíblia é rica, por sua vez, demanda um esforço por resgatar as características estruturais do próprio material, dos significantes (parte do que forma estritamente uma "obra aberta"). Além disso, o Tanach não é constituído por apenas um texto, mas por coleções de coletâneas e possúi vários autores que nem sempre escreveram numa mesma língua - o livro de Esdras, por exemplo, contém partes escritas em aramaico. A escrita do Tanach se estendeu por mais de um milênio antes de o texto ser "sacralizado" e, num certo sentido, fechado, e, por esse tempo, o hebraico sofreu grandes modificações. Isso impõe ao texto uma imensa diversidade lingüística e uma distância quase insuperável.

Como a linguagem do Tanach possui todas essas dificuldades, demanda leituras diversas: a tradição judaica possui uma vasta pluralidade de interpretações e isso configura uma produção mais democrática do saber. A Mishná e o Midrash, por exemplo, registram discussões com um princípio de igualdade do valor das interpretações. Isso reflete a descentralização do poder religioso judaico. Essa democracia da produção do saber também se destaca pelo fato de que os judeus "tinham o ensino obrigatório a partir do século 1 . Aos 13 anos os meninos já liam a Tora" diretamente no texto bíblico (p. 245). Com o cristianismo aconteceria o contrário, na medida em que, ao possuir um poder centralizado, mantém o monopólio de uma interpretação dogmática. A Inquisição foi, por muitos séculos, responsável por punir com violência e assassinato toda a oposição à interpretação oficial da Igreja. Após a Reforma e o surgimento da imprensa, a Bíblia torna-se acessível pelo custo, que caiu exponencialmente, e pela tradução, que facilitou a leitura. Assim, as pessoas puderam, com acesso direto ao texto, conferir e questionar as interpretações oficiais. A partir dessa abertura, o cristianismo já não se reduz à Igreja católica e, atualmente, são conhecidas inúmeras religiões que se apóiam sobre o mesmo texto: a Bíblia Hebraica e o chamado Novo Testamento.

O estudo de Malanga tem uma acertada pertinência ética e universal, posto que ele desarma as leituras dogmáticas e fundamentalistas que já deram ensejo tanto a crimes, que toda a história registra, feitos em nome de Deus e de suas palavras, quanto à proibição da linguagem - censura e incriminação 
por heresia. Como Roland Barthes se refere em $S / Z$, "toda dominação começa por proibir a linguagem".

A pluralidade de sentidos, tudo o que dificulta a determinação unívoca, e a estrutura poética que caracteriza a "obra aberta" podem parecer defeitos aos olhos racionalistas, ao lerem o Tanach mas, "Na realidade, essa abertura, resultante de uma ambigüidade às vezes desejada, outras vezes casual, associada à interpretação ampliativa, é que possibilitou a sobrevivência do texto bíblico" (p. 119), pois ela gerou e ainda gera discussões e interpretações inesgotáveis e, portanto, sua abertura é a sua riqueza. Além do mais, o respeito à diversidade, que, como se viu, tem profunda afinidade com a tolerância, é capaz de fazer o bem: "como 'a linguagem não é só reflexo, reprodução ou reiteração da práxis', ela tem também a capacidade de 'desenvolver uma ação dialética e criativa na medida em que desarranjar a práxis e os corredores isotópicos e desmontar os corredores perceptuais"' (p. 220). Se é importante a estabilidade da linguagem para que possam acontecer os atos comunicacionais, também é importante esse caráter subversivo da estrutura poética para que não se tome por natural o que é criação ficcional.

* Glauber Pereira Quintão é aluno do curso de Filosofia da Universidade Federal de Minas Gerais, pesquisador do Núcleo de Estudos Judaicos da UFMG e bolsista de Iniciação Científica do CNPq. 